\title{
Free Cash Flow, Dividend Policy and Leverage: Do Growth Opportunities Matter? Empirical Evidence From Egyptian Stock Exchange
}

\author{
Shaimaa Fekry Mehanna \\ Department of Accounting, Faculty of Commerce, Zagazig University, \\ Zagazig, Egypt
}

\begin{abstract}
Purpose - The purpose of this study is to examine the relationship between free cash flow and dividend policy in an emerging capital market - Egypt.

Design/Method - Using pooled cross-sectional data from the top 50 listed Egyptian companies during 2013 - 2016, this study examines the relationship between free cash flow and dividend policy as well the moderating role of growth opportunities.

Findings - An insignificant association was found between free cash flow and dividend size as well with dividend payouts after controlling for several firm-level characteristics that could influence corporate's dividend policy. The study also found that, in the presence of growth opportunities, the relationship of free cash flow and dividend size was not affected, suggesting that growth opportunities did not play a moderating role, same conclusion for dividend payouts. Further, the study found significant positive association between the level of free cash flow and financial leverage. Overall, the results suggested that financial leverage is a better control mechanism than dividends to reduce the agency costs of free cash flow in the Egyptian companies.
\end{abstract}

Keywords Egypt, Free Cash Flow, Dividends Policy, Financial Leverage, Growth Opportunities

Paper type Research paper

\section{INTRODUCTION}

Resources generated through a firm's profit-making activities can be allocated between two competing uses: paying out dividends or funding worthwhile opportunities (Cheng et al., 2014). Efficient allocation of a firm's excess resources is vital for its growth, shareholders' wealth maximization and sustainability (Afza and Mirza, 2014). Striking a balance between paying out dividends to shareholders, when there are excess resources (i. e. free cash flow), while retaining sufficient resources to finance worthwhile investments help avoid overinvestment in 
inappropriate projects and other potential misuses of a firm's resources by opportunistic managers for their own benefits (Cheng et al., 2014).

Setting out dividend policy has always been a subject of controversial debate in literature (Parsian and Koloukhi, 2013; Subramaniam et al., 2014; Giriati, 2015). Prior literature reveals several theoretical perspectives to explain corporate dividend policy; the first theoretical explanation, which relies on signalling theory, suggests that management has more firsthand information about firm's future cash flow than investors do (Ullah et al., 2012) and has incentives to signal that information to the market in order to create credible relationships (Abdelsalam et al., 2008), reduce information asymmetries (Gul, 1998; Ghalandari, 2013; Giriati, 2015) and ensure that their companies have better earnings prospects (Subramaniam et al., 2011; Subramaniam et al., 2014).

Afza and Mirza (2014) stressed maintaining a balance between payouts and retention rates, since more than optimal dividend payouts may enhance company's image but will exert negative pressure on company's reserves. On the other side, low dividend payouts signal weak financial position and mismanagement of company's financial affairs, which may jeopardize company's image and create difficulties in raising external funds from capital market. Wijaya and Felix (2017) argued that an appropriated dividend policy is determined after comparing funds required to finance the available growth opportunities with expected payout ratio by shareholders. Dividend policy is expected to create a balance between current dividend payouts with company's growth opportunities in order to maximize shareholders' value.

The second theoretical explanation, which relies on agency theory, suggests that dividend policy can play a crucial role in aligning the conflicting interests inherent in principal-agent relationship (Abdelsalam et al., 2008; Ullah et al., 2012). Jensen (1986) states that higher payouts decrease excess resources that can be squandered away by managers. Gul (1998) and Giriati (2015) support the notion that higher dividend payouts decrease resources under managerial control so help mitigate agency costs. Rozeff (1982) argues that dividend payouts are part of a firm's monitoring and bonding package that help mitigate agency costs. Jensen (1986) argues that managers with excess resources (i. e. substantial free cash flow) can pay higher payouts or buyback stocks in order to use the abundant cash flow 
that would otherwise be used in low-return investments, or directed towards their own private benefits (Ullah et al., 2012). Khan et al. (2012), Cheng et al. (2014) and Giriati (2015) suggest that managers can engage in opportunistic activities that are good for themselves, including overconsumption and investing in unnecessary projects to enhance their compensation and personal prestige (i. e. over-investment) but not beneficial to shareholders, and this potential over-investment is exacerbated in firms with substantial level of free cash flow.

The third theoretical explanation, which relies on free cash flow hypothesis, suggests that firms with free cash flow more than what are required by managers to be invested in positive NPV projects, they may utilize the excess cash in low-return projects or waste it (i. e. over-investment) (Jensen, 1986; Stouraitis and Wu, 2004; Khan et al., 2012). The free cash flow hypothesis stresses the negative consequences of potential misuses of excessive cash flow (i. e. free cash flow problem) under the discretionary control of opportunistic managers for their own benefit (Khan et al., 2012; Ghalandari, 2013; Sualehkhattak and Hussain, 2017).

Prior literature reveals alternative mechanisms to control the potential misuse of excessive free cash flow under discretionary control of managers; Wu (2004), Khan et al. (2012), Ullah et al. (2012) and Kargar and Ahmadi (2013) argue that institutional shareholders can play a disciplinary role and discourage managerial overspending; they do not directly monitor firm operations but they force the opportunistic managers to spend available cash flow that was internally generated in profitable projects and to avoid wasteful expenditures. Cheng et al. (2014) also argue that cross-listing can be used as a control mechanism to control potential misuse of excessive free cash flow, since cross-listed firms subject to greater scrutiny by foreign regulators and foreign shareholders, which in turn reduces the risk of potential overinvestment than those of non-cross-listed firms.

Debt also can be used as another mechanism to decrease free cash flow under discretionary control of managers (Jensen, 1986; Ghalandari, 2013; Hejazi and Moshtaghin, 2014; Sualehkhattak and Hussain, 2017). High leverage restricts firm's available resources (i.e. free cash flow) from being inefficiently used by managers by giving it directly to company's debt holders in the form of interest and principal payments (Khan et al., 2012; Nurul and Iqbal, 2015). This reduction in firm's available resources also reduces expenditure on managerial prerequisites (Mirza and 
Afza, 2014). Dividend payments can be also used as an alternative mechanism to decrease the discretionary resources under managerial control; higher payouts decrease the chance of being inappropriately used by inefficient managers (Cheng et al., 2014). Stouraitis and Wu (2004) and Abdelsalam et al. (2008) support the notion that marinating higher payouts decrease the level of free cash flow that managers can use at their discretion, thereby reducing the potential over-investment in unnecessary projects; these unnecessary investments can lead to poor economic performance that increases the agency conflicts between managers and shareholders, hence, come the disciplinary role of payouts to restrain managers' unprofitable expansionary tendencies by restricting financial resources under their control.

Stouraitis and $\mathrm{Wu}(2004)$ also argue that these agency conflicts between the managers and shareholders about dividend payouts vary according to the available growth opportunities. Rozeff (1982) suggests that firms should set a lower payout ratio when they experiencing higher growth opportunities, presumably these available growth opportunities entail higher investment expenditures. Cheng et al. (2014) argue that appropriated dividend policies increasing payouts when firms have excess resources (i. e. free cash flow) to restrain managerial ability from making inappropriate investment decisions, especially in the absence of positive NPV projects, while lessening payouts when firms have good growth prospects to retain sufficient resources to fund these available growth opportunities.

This study examines how the relationship between free cash flow and dividend policy varies cross-sectionally with firm's growth opportunities. Given the severity of the over-investment problem, this study contributes to the literature in two ways; First, the present study is going to examine the effect of free cash flow on dividend policy since an important body of existing literature focused on examining the influence of list of factors such as ownership structure, board characteristics, liquidity, profitability and cross-listing as determinants of dividend payouts, compared to literature that focused on investigating the direct impact of free cash flow on dividend policy, especially in the Egyptian market. Second, no sufficient evidence has yet been found on the moderating role of growth opportunities on the relationship between the level of free cash flow with dividend policy which is virtually worth further investigation, especially for listed companies in the Egyptian stock exchange. The current study is going to fill this gap in the 
research and check whether firm's growth opportunities influence the relationship of free cash flow with dividend policy?

The rest of the paper is organized as follows: section 2 reviews the relevant literature and presents the theoretical relationship between free cash flow and dividend policy, while explaining the moderating role of growth opportunities. Section 3 describes the research method including sample selection, data sources and model specification. Section 4 presents discussion of results. Section 5 presents the conclusion.

\section{LITERATURE REVIEW AND HYPOTHESES DEVELOPMENT}

\subsection{Free cash flow and Dividend policy}

High level of free cash flow permits managers to directly invest internallygenerated capital in positive NPV investments that will maximize shareholder value. However, when free cash flow is greater than what is required to be invested in positive NPV projects, managers may utilize this excess cash for their own private benefits rather than for shareholders' benefits, thereby increasing the agency costs (Khan et al., 2012; Ghalandari, 2013; Cheng et al., 2014). One possible way to mitigate agency costs associated with the excessive levels of free cash flow is to distribute higher dividends to shareholders (Jensen, 1986; Ullah et al., 2012). Consistent with this notion, research indicates that firms with higher levels of free cash flow have higher dividend payouts. Kangarlouei et al. (2014) examined the impact of free cash flow on dividend policy and found that free cash flow had a positive significant relationship on dividend payments. Kangarlouei et al. (2014) reported that dividend payments could mitigate the agency costs of free cash flow by reducing cash flow under discretionary control of managers. So, firms with high free cash flow are under more pressure to pay dividends, however, this could result in under investment if the cash paid out is needed later to finance worthwhile investments.

In contrast, Parsian and Koloukhi (2013) reported different results. They investigated the impact of various factors (e.g. free cash flow, leverage, size, growth opportunities and systematic risk) on dividend payouts of listed companies in Tehran Stock Exchange (TSE) during 2005 - 2010. Their results showed that free cash flow had a significant negative impact on dividend payouts; whereas, leverage 
had a significant positive impact on dividend payouts. Other variables such as size, growth opportunities and systematic risk did not have any significant influence on payout ratio. In the same vein, Wijaya and Felix (2017) analyzed various factors that may affect the dividend policy of non-financial firms (e.g. free cash flow, leverage, growth opportunities, liquidity, profitability, ownership structure, earnings per share, size, and floating rate). Wijaya and Felix (2017) found that free cash flow, leverage, growth opportunities, liquidity, ownership structure, firm size and profitability, had no effect on dividend policy, while dividend policy is affected by earnings per share and free floating rate. Similarly, Giriati (2015) found an insignificant association between free cash flow and dividend payouts.

On the other side, the results of Hejazi and Moshtaghin (2014) supported the notion that financial leverage is an alternative controlling mechanism to dividend policy to reduce the agency costs of free cash flow. Their results showed that high levels of the free cash flow are associated with high dividend payouts ratio and high financial leverage. In line with this notion, Kargar and Ahmadi (2013) argued that dividend policy and financial leverage are used to control free cash flow problem. However, their results indicated a positive insignificant association between free cash flow and dividend payouts while a significant positive association between free cash flow and leverage. The results of Kargar and Ahmadi (2013) supported the notion that financial leverage is considered as a better controlling mechanism than dividend policy regarding agency costs of free cash flow, because by issuing debt, managers are obligated to pay out the future cash flow in such a way that could not be accomplished by promises to increase cash dividends.

Tijjani and Sani (2016) investigated the impact of free cash flow on dividend policy and documented a positive insignificant association between free cash flow and dividend payouts. They also examined the association between leverage and dividend payouts and found a significant negative association between leverage and dividend payouts. Possible interpretation argues that higher dividend payments decrease cash flow under control of managers, which in turn, enforces them to raise external funds from capital markets (i.e. leverage) in order to finance worthwhile investment opportunities which put them under greater scrutiny by lenders and market experts. In addition, this reduction in free cash flow reduces the managerial expenditure on prerequisites and unprofitable investments (i.e. reduced agency 
conflicts). However, as a result of reduced cash flow, the firm's ability to pay high dividends also negatively affected.

Findings of Tijjani and Sani (2016) supported the results of Nurul and Iqbal (2015) that reported an inverse relationship between dividend payments and financial leverage. Nurul and Iqbal (2015) also examined the association between free cash flow and leverage and found a positive and significant association between free cash flow and debts. In the same vein, Khan et al. (2012) found evidence revealing that leverage is used as a control mechanism to mitigate agency costs of free cash flow by decreasing free cash flow under discretionary control of managers. Khan et al. (2012) argue that high leverage restricts opportunistic managers in firms with high level of free cash flow from being inefficiently used by given it directly to the debt holders in the form of interest and principal payments.

Hashemi and Zadeh (2012) also supported the argument that leverage and dividends are substitutes; they suggested a negative causal relation between debt levels and dividend payments among Tehran Stock Exchange (TSE) listed companies during 2003 to 2010. High leverage enforces managers to save internal financial resources in order to serve debts and then, lower cash will be distributed to shareholders. Hashemi and Zadeh (2012) also investigated the impact of operating cash flow on dividend policy and suggested a positive relationship between operating cash flow and dividend policy. Mirza and Afza (2014) supported the preceding results. They investigated the impact of operating cash flow on dividend payouts in four in four emerging economies of South Asia i.e. Bangladesh, India, Pakistan and Sri Lanka during 2006 - 2010. Their results evidenced that operating cash flow is an important factor affecting dividend payouts, especially in India and Pakistan, where in Sri Lanka and Bangladesh, dividend payouts were not affected too much by operating cash flow. Similar results have been observed using dividend yield and dividend intensity which confirmed the estimated results from dividend payout.

However, the reported results of Hashemi and Zadeh (2012) and Mirza and Afza (2014) used operating cash flows to explain dividend policy as it is considered the most important source of dividend payments, while operating cash flow has been shown to be inadequate since it did not consider capital expenditures and dividends should be paid out of the residual left after capital investment decisions, 
while free cash flow is the available cash to managers before discretionary capital investment decisions. Based on the preceding discussion, a positive association is expected between the level of free cash flow and dividends:

Hypothesis I: there is a positive relationship between the level of free cash flow and dividends.

\subsection{Free cash flow, Growth opportunity and Dividend policy}

\section{(The moderating role of growth opportunities)}

The free cash flow hypothesis is based on concerns that managers may direct too much cash to be invested in inappropriate projects (i. e. potential overinvestment) (Cheng et al., 2014). One way to discipline inefficient managers is to distribute higher dividends to decrease the free cash flow that managers can use at their discretion (Abdelsalam et al., 2008). However, the disciplinary role of dividend payouts over potential overinvestment varies according to firm's growth opportunities (Stouraitis and $\mathrm{Wu}, 2004)$. Firms with greater growth opportunities could profitably direct the excess resources in such a way that permits to take advantage from these opportunities (Cheng et al., 2014). Such firms are more likely to retain cash flow rather than paying them out to shareholders since both objectives of shareholders and managers are more likely to coincide (Stouraitis and $\mathrm{Wu}, 2004$ ), whereas the divergence of interests between shareholders and managers over dividend payouts ratio are more severe in firms with lower growth opportunities to restrain managers from taking inappropriate investment decisions in the absence of worthwhile opportunities (Jensen, 1986). Consistent with the preceding notion, prior research revealed that firms with better growth opportunities paid out lower or no dividends. Ghalandari (2013) ${ }^{(1)}$ and Sualehkhattak and Hussain (2017) ${ }^{(2)}$ confirmed the significance of firm growth opportunities on dividend policy. They

\footnotetext{
1 - Ghalandari (2013) investigated the moderating effect of growth opportunities on the relationship between leverage, dividend policy with Firm Value and documented a significant negative relationship between leverage and dividend and firm value which in the presence of growth opportunities, but in of absence of growth opportunities, there was positive and significant relationship.

2 - Sualehkhattak and Hussain (2017) examined the moderating role of growth opportunities in the relationship between leverage, dividend payout with firm value and documented an insignificant interaction between leverage and growth opportunities and insignificant interaction between dividend payout and growth opportunities, showing that in presence of growth opportunities dividend payout does not play any significant role in enhancing firm value.
} 
argue that the overinvestment problem arises in firms with no or low-growth opportunities compared with firms with high-growth opportunities.

Stouraitis and $\mathrm{Wu}$ (2004) argued that the overinvestment problem is less important in firms with greater growth opportunities since both objectives of shareholders and managers are more likely to coincide. Stouraitis and $\mathrm{Wu}$ (2004) used a sample of 986 observations form 350 Japanese listed firms during 1992 2000 and examined the implications of free cash flow hypothesis on dividend policy. Their findings suggested a positive relationship between the level of free cash flow and dividend payouts and this relationship is stronger for low-growth firms than for high-growth firms since management's temptation to overinvest could be restricted by paying out higher dividends. Stouraitis and $\mathrm{Wu}$ (2004) found evidence supporting the notion that dividend policy is used by Japanese low-growth firms to reduce managerial abuse of discretionary funds to avoid potential overinvestment.

Consistent with the preceding results, Gul (1998) investigated the relationship between investment opportunity set (IOS) and dividend policy among Japanese listed firms using a sample of 5308 observations for five years from 1988 to 1992. He found a significant negative relationship between growth opportunities and dividend yields. Gul (1998) also examined the relationship between IOS and levels of debt financing and documented the same results. Similarly, the results of Giriati (2015) supported a negative association between IOS and dividend payouts since the profits used for dividend payments reduce cash flow kept to finance available investment opportunities.

Kargar and Ahmadi (2013) examined the impact of free cash flow on dividend payouts. They found a positive but insignificant association between free cash flow and payouts for both high and low-growth firms. The results of Bhabra and Luu (2015) not only corroborated the findings in the literature of a negative relationship between growth opportunities and dividend payouts but also demonstrated a causal linkage where changes in firm's growth opportunities cause changes in payout policy for a sample of large US defense firms at the end of the Cold War. Particularly, when growth opportunities of US defense firms deteriorated at the end of Cold War, firms responded by increasing total dividend payouts. However, they found strong evidence that increases in dividend payouts were 
achieved largely through share buybacks rather than an increase in dividend payouts. Based on the preceding discussion, it is expected that high-growth firms are more likely to pay out lower dividends than low-growth firms to benefit from the growth opportunities. For this reason, a stronger relation is expected between free cash flow and dividends for low-growth firms than high-growth firms:

Hypothesis II: the relation between the level of free cash flow and dividends is positive and stronger for firms with low growth opportunities than high growth opportunities.

\section{DATA AND METHODOLOGY}

\subsection{Sample and data sources}

The initial sample covers the 50 highest capitalized and most active listed companies in the Egyptian stock exchange (EGX EWI 50) during 2013 - $2016^{(3)}$. For each year, companies are ranked according to their year-end market-to-book ratio of equity MKT/BKEQTY (Growth Opportunities). Then, the sample was divided into two groups: the first group consisted of the top 40\% of MKT/BKEQTY rates (firms having the most growth opportunities); the second group consisted of the bottom $40 \%$ of MKT/BKEQTY rates (firms having the least growth opportunities); and the rest is eliminated from the analysis. Similar percentage classifications are used in (Gul, 1998; Stouraitis and Wu, 2004; Ghalandari, 2013; Sualehkhattak and Hussain, 2017) in order to evaluate firm's growth opportunities.

Some prior studies had performed separate regression analysis for high and low growth firms after eliminating the middle firms from the sample (e.g. Stouraitis and Wu, 2004; Ghalandari, 2013; Sualehkhattak and Hussain, 2017). In the current study, the regression analysis will be performed for the whole sample whereas the moderating variable (e.g. growth opportunities) will be a dummy variable equals to (1) for high growth firms, zero otherwise (e.g. Gul, 1998). The final sample

\footnotetext{
3- The companies listed in EGX EWI 50 accounted for almost 75 per cent of the total market capitalization of the Egyptian stock exchange, whereas, the companies listed in EGX 30 accounted for almost 56 per cent of total market capitalization of the Egyptian stock exchange. The companies listed in EGX 70, which tracks the performance of the 70 active companies, after excluding the 30 most active constituent-companies of EGX 30 Index, accounted for almost 30 per cent of total market capitalization of the Egyptian stock exchange during 2016. retrieved from http://egx.com.eg/English/Indices.aspx
} 
contained 134 firm-year observations over the study period 2013 - 2016 after excluding firms with missing data.

Data on dividend policy, free cash flow, growth opportunities and various control variables were collected from published annual reports. Data on the top 50 listed companies in EGX EWI 50 was collected from the website of the Egyptian stock exchange. Furthermore, to cover some missing financial information, the Egyptian stock exchange website and Mubasher Misr Database were used.

\subsection{Model Specification}

The study uses panel data regression model to examine the relationship between the level of free cash flow and dividend policy. The main regression model used is given by:

$$
\mathrm{Y}_{\mathrm{it}}=\beta+\mathrm{b} \mathrm{X}_{\mathrm{it}}+\varepsilon_{\mathrm{it}}
$$

Where,

$\mathrm{Y}=$ Dependent variable (DP), $\mathrm{X}=$ Independent and control variables (FCF, FGOP, FSIZE, FLVG, FPROF), $\beta+b=$ coefficients, $\varepsilon=$ error term, $i$ and $t=$ crosssectional and time series dimensions.

The following model is constructed to provide empirical testing to the study's hypotheses:

$$
\begin{aligned}
& D P_{i t}=\beta_{0}+\beta_{1}(F C F)_{i t}+\beta_{2}(G W O P R)_{i t}+\beta_{3}(F C F)_{i t} *(G W O P R)_{i t}+\beta_{4} \\
& (F P R O F)_{i t}+\beta_{5}(F S I Z E)_{i t}+\beta_{6}(F L E V G)_{i t}+\varepsilon_{i t}
\end{aligned}
$$

Where,

Corporate dividend policy is represented by three proxies; the first proxy is Dividend size (DIVIDSIZE). Dividend size $=$ Cash dividends/Total assets. The second proxy is dividend payout (DIVIDPAYOUT). Dividend payouts $=$ cash dividends per share/Earnings per share. These proxies for dividend policy had been widely used in many prior studies (e.g. Gul, 1998; Stouraitis and Wu, 2004; Mirza and Afza, 2014; Giriate, 2014; Kangarlouei et al., 2014; Subramaniam et al., 2014; Nurul and Iqbal, 2015). 
The key independent variable is: free cash flow (FCF). Jensen (1986) defines free cash flow as the cash flow left after the firm has invested all available positive NPV projects. Several researchers used different measures to calculate free cash flow. Stouraitis and Wu (2004), Khan et al. (2012) and Cheng et al. (2014) defined free cash flows as operating income before depreciation, interest expense and taxes divided by book value of assets. In this study, free cash flow (FCF) is measured by subtracting a company's capital expenditures from its operating cash flow divided by book value of assets. This measure has also been used in (Giriati, 2015; Tijjani and Sani, 2016; Wijaya and Felix, 2017). The larger FCF the greater the value of free cash flow compared to the value of total assets. It is expected that the greater FCF the greater the chances of dividends are being paid out. The coefficient of free cash flow is expected to be positive.

Growth opportunities (GWOPR) is a moderator variable. Market-to-book ratio of equity is used to measure firm's growth opportunities (GWOPR). The higher the MKT/BKEQTY ratio, the higher the firm value because of the presence of growth opportunities and vice versa. Market-to-book ratio of equity MKT/BKEQTY $=($ Shares outstanding/issued $\mathrm{x}$ Share closing price $) /$ Total book value of common equity ${ }^{(4)}$. Growth opportunity is a dummy variable which is equal to (1) for high-growth subsample which are placed in the top $40 \%$ rank of MKT/BKEQTY, (0) for low-growth subsample which are placed in the bottom $40 \%$ rank of MKT/BKEQTY.

Growth opportunities represent the discretionary expenditures in the future that will be charged by the company and will affect the value of the company which will be reflected in the market value of its shares (Giriate, 2014). Therefore, MKT/BKEQTY is the most informational content in relation to investment opportunities. It measures the present value of future cash flow to shareholders from both assets in place and future investment opportunities (Subramaniam et. al., 2014). This measure had been extensively used in most prior studies (e.g., Gul, 1998; Stouraitis and Wu, 2004; Subramaniam et al., 2011; Ghalandari, 2013; Cheng et al., 2014; Giriate, 2014; Subramaniam et al., 2014; Nurul and Iqbal, 2015; Sualehkhattak and Hussain, 2017). Thus, the present study uses MKT/BKEQTY as

\footnotetext{
4- Book value of equity is the equivalent of total assets less total liabilities and preferred equity. In other words, the book value of equity represents the equity of shareholders (from a balance sheet perspective) less the preferred stock.
} 
a measure for growth opportunities, since it is an efficient indicator and allows comparison of present study to other ones.

Consistent with prior literature, the following explanatory variables for controlling other firm-level characteristics that could influence a firm's dividend policy are used in the analysis. Firm size (FSIZE), the natural log of total assets is used to measure firm size. Larger firms are generally viewed as having more stable cash flow. The coefficient on firm size is hypothesized to be positive. Profitability (FROE), return on equity ratio is used as a proxy for firm profitability. Firms with higher profits are willing to pay out higher dividends to signal their performance. The coefficient of profitability is expected to be positive. Leverage (FLEVG), Debt/Asset ratio is used to measure the financial leverage. Leverage is an alternative mechanism to disgorge excess free cash flow (Jensen, 1986). Nurul and Iqbal (2015) and Tijjani and Sani (2016) reported a negative causal relationship between debt levels and dividend payments. Hejazi and Moshtaghin (2014) also supported the argument that leverage and dividends are substitute. It is expected that firms that rely more on leverage to disgorge free cash flow will rely less on dividends. Leverage's coefficient is expected to be negative.

\section{RESULTS AND DISCUSSION}

\subsection{Descriptive Statistics and Correlation Analysis}

Table (1) presents a summary for key descriptive statistics for the dependent and independent variables used in the analysis. Concerning the proxies of dividend policy, dividend size has a mean of 0.0350 and a median of 0.009 with minimum and maximum values of 0.00 and 0.31 . Dividend payout has a mean of 0.484 and a median of 0.243 . Free cash flow shows a mean of 0.150 and a median of 0.059 with minimum and maximum values of -1.14 and 3.25 , respectively, reflecting that the level of free cash flow varies significantly across the companies.

Turning to the other control variables, profitability varies across the sample between a minimum value of -31.7 (loss) and maximum value of 5.50 (maximum

profit), with standard deviation equal to 0.491 . Firm size indicates that firms are widely dispersed with values vary between 19.12 (approximately 220 million of EGP) as the minimum value and 26.31 (approximately 870 million of EGP) as the maximum value, respectively. Financial leverage ratio has a mean of 0.471 with 
minimum and maximum values of 0.00 and 0.96 , respectively, which reflects that firms depend significantly on financing by debts, with a correspondingly median value of 0.417 and a standard deviation of 0.2708 .

Table (1)

Descriptive Statistics

\begin{tabular}{|l|c|c|c|c|c|c|}
\hline & Mean & Median & $\begin{array}{c}\text { Std. } \\
\text { Deviation }\end{array}$ & Range & Minimum & Maximum \\
\hline DIVIDSIZE & $\mathbf{0 . 0 3 5 0}$ & $\mathbf{0 . 0 0 9 2}$ & $\mathbf{0 . 0 6 1 3 8}$ & $\mathbf{0 . 3 1 2 0}$ & $\mathbf{0 . 0 0 0}$ & $\mathbf{0 . 3 1 2 0}$ \\
\hline DIVIDPAYOUT & $\mathbf{0 . 4 8 4 9}$ & $\mathbf{0 . 2 4 3 0}$ & $\mathbf{1 . 2 5 5 7 8}$ & $\mathbf{1 5 . 7 9 0}$ & $\mathbf{- 3 . 4 4 9}$ & $\mathbf{1 2 . 3 4 1}$ \\
\hline FCF & $\mathbf{0 . 1 5 0 6}$ & $\mathbf{0 . 0 5 9 1}$ & $\mathbf{0 . 5 3 9 0 4}$ & 4.398 & $-\mathbf{1 . 1 4 0 7}$ & $\mathbf{3 . 2 5 7}$ \\
\hline GWOPR & $\mathbf{0 . 6 0 2 6}$ & 1.0000 & $\mathbf{0 . 4 9 0 9 8}$ & 1.000 & $\mathbf{0 . 0 0 0}$ & $\mathbf{1 . 0 0 0}$ \\
\hline FROE & $\mathbf{0 . 1 9 3 1}$ & $\mathbf{0 . 1 1 4 6}$ & $\mathbf{0 . 4 9 0 7 4}$ & $\mathbf{5 . 8 1 8}$ & $\mathbf{- 0 . 3 1 7}$ & $\mathbf{5 . 5 0 1}$ \\
\hline FSIZE & $\mathbf{2 2 . 3 3 1 8}$ & $\mathbf{2 2 . 1 5 1 6}$ & $\mathbf{1 . 4 8 8 7 2}$ & $\mathbf{7 . 1 8}$ & $\mathbf{1 9 . 1 3}$ & $\mathbf{2 6 . 3 1}$ \\
\hline FLEVG & $\mathbf{0 . 4 7 1}$ & $\mathbf{0 . 4 1 7}$ & $\mathbf{0 . 2 7 0 8}$ & $\mathbf{0 . 9 5 9}$ & $\mathbf{0 . 0 0 2}$ & $\mathbf{0 . 9 6 1}$ \\
\hline
\end{tabular}

Following the descriptive analysis of the variables, Table (2) presents Pearson's correlation matrix. The correlation matrix shows that the correlations' degree between explanatory variables are either low or moderate; the highest correlation coefficient in the sample exists between financial leverage (FLEVG) and firm size (FSIZE), with a coefficient of 0.477 , suggesting absence of multicollinearity between the independent variables. Pearson's coefficient between each pair of independent variables should not exceed 80\%; otherwise, they may be suspected to exhibit multi-collinearity (Abdelsalam et al., 2008).

The correlation matrix shows that free cash flow (FCF) has insignificant correlations with dividend size (DIVIDSIZE) and dividend payouts (DIVID PAYOUT), which are opposite to what was expected. On the other hand, the correlation between free cash flow (FCF) and financial leverage (FLEVG) is statistically significant. The preceding correlations' results indicate that Egyptian firms with higher level of free cash flow are more likely to use debts rather than dividends to reduce the agency costs of free cash flow, as high leverage could restrict firm's excess resources from being inefficiently used by opportunistic managers through paying it to debt holders in the form of interest and principal payments. These results are consistent with the results of Kargar and Ahmadi (2013) and Hejazi and Moshtaghin (2014) who argued that financial leverage is alternative control mechanism to reduce the agency costs of free cash flow. The 
correlations between dividend size (DIVIDSIZE) and dividend payouts (DIVIDPAYOUT) with financial leverage (FLEVG) are statistically significant and supported the notion that high leveraged firms pay out lower dividends because they have to put interest and principal payments to creditors at the forefront.

The correlation matrix shows that growth opportunities (GWOPR) have a positive and significant correlation with dividend size (DIVIDSIZE), whereas insignificant correlations with dividend payouts (DIVIDPAYOUT), which are opposite to what was hypothesized that high-growth firms pay out lower dividends since they need more funds to finance their growth. As firms grow, they need to allocate more out of their financial resources to finance further investments (Wijaya and Felix, 2017).

Table (2)

Correlations Matrix

\begin{tabular}{|c|c|c|c|c|c|c|c|}
\hline & \begin{tabular}{|c|} 
DIVID \\
SIZE \\
\end{tabular} & $\begin{array}{c}\text { DIVID } \\
\text { PAYOUT }\end{array}$ & FCF & GWOPR & FROE & FSIZE & FLEVG \\
\hline \multirow{2}{*}{$\begin{array}{l}\text { DIVID } \\
\text { SIZE }\end{array}$} & 1.000 & & & & & & \\
\hline & & & & & & & \\
\hline \multirow{2}{*}{\begin{tabular}{|l} 
DIVID \\
PAYOUT
\end{tabular}} & $0.221 *$ & 1.000 & & & & & \\
\hline & $(0.011)$ & & & & & & \\
\hline \multirow{2}{*}{ FCF } & 0.079 & -0.010 & 1.000 & & & & \\
\hline & $(0.364)$ & $(0.906)$ & & & & & \\
\hline \multirow{2}{*}{ GWOPR } & $0.258^{* * *}$ & 0.119 & 0.069 & 1.000 & & & \\
\hline & $(\mathbf{0 . 0 0 3 )}$ & $(0.171)$ & $(0.430)$ & & & & \\
\hline \multirow{2}{*}{ FROE } & 0.064 & \begin{tabular}{|l|}
-0.038 \\
\end{tabular} & -0.079 & $0.223 * *$ & 1.000 & & \\
\hline & $(0.464)$ & $(0.667)$ & $(0.363)$ & $(0.010)$ & & & \\
\hline \multirow{2}{*}{ FSIZE } & -0.154 & -0.020 & $0.350 * *$ & 0.034 & 0.080 & 1.000 & \\
\hline & $(0.075)$ & $(0.820)$ & $(0.000)$ & $(0.697)$ & $(0.358)$ & & \\
\hline \multirow{2}{*}{ FLEVG } & $-0.278 * *$ & $-0.228 * *$ & $0.234 * *$ & $0.302 * *$ & 0.188* & $0.477 * *$ & 1.000 \\
\hline & \begin{tabular}{|l|}
$(0.001)$ \\
\end{tabular} & $(0.008)$ & $(0.006)$ & $(0.000)$ & $(0.029)$ & $(0.000)$ & \\
\hline
\end{tabular}

Notes: $\left(^{* *}\right)$ indicates significance at the 0.01 level or better. $\left(^{*}\right)$ indicates significance at the 0.05 level (two-tailed). P-values are shown in parenthesis. 


\subsection{Regression Analyses}

In order to generalize the regression model, the following underlying crossvalidating assumptions (i.e. auto-correlation, normality for distributed errors and multi-collinearity) are checked to assure that they have been met. Table (3) presents the regression results examining the potential impact of free cash flow (FCF) on dividend policy represented by dividend size (DIVIDSIZE) as well the potential interactive effect of firm's growth opportunities on the relationship between free cash flow with dividend size (Hypotheses I and II). The model is significant $(\mathrm{F}=6.476, \mathrm{P}-\mathrm{Value}<0.05)$. The combination of the independent variables explains $8.80 \%$ of the variations in dividend size. The coefficient estimate for free cash flow (FCF) is (0.007) with t-statistics of (0.377). Free cash flow has positive insignificant relation with dividend size. This result is inconsistent with what was hypothesized in $\mathrm{H} 1$ that firms with higher levels of free cash flow have higher dividends size.

Growth opportunity (GWOPR) has coefficient estimate of (0.030) with tstatistics of (2.862). Growth opportunity (GWOPR) has positive significant relation with dividend size. This result indicates that firms with higher growth prospects pay out higher dividends. This finding is inconsistent with what was expected that highgrowth firms are more likely to pay lower dividends than low-growth firms in order to benefit from the available investment opportunities. The interaction of free cash flow and growth opportunity (FCF*GWOPR) is not significant and reflects growth opportunities do not play a moderating role on the hypothesized relationship of free cash flow and dividend size. This result is inconsistent with $\mathrm{H} 2$, which posited that high growth firms are more likely to retain the excess resources rather than pay them out to shareholders in the form of dividends to take advantage from the available growth prospects.

Turning to other control variables, the coefficient estimates for firm profitability (FROE) and for firm size (FSIZE) indicated no significant relationship with dividend size. However, for financial leverage (FLEVG), the coefficient estimate indicates a statistically significant negative relationship with dividend size, which are in line with the expectations and previous research. Financial leverage appears to have a negative causal relationship with dividends size. This finding supported the view of Roseff (1982) that dividend payments are quasi-fixed charges which are considered substitutes for other fixed charges (i. e. interest payments). 
Table (3)

Dividend Policy represented by Dividend Size (DIVIDSIZE)

\begin{tabular}{|l|c|c|c|c|c|}
\hline & $\begin{array}{c}\text { Predicted } \\
\text { Sign }\end{array}$ & Coefficient & $\begin{array}{c}\text { t. } \\
\text { statistics }\end{array}$ & Sig. & VIF \\
\hline Intercept & & $\mathbf{0 . 1 1 1}$ & $\mathbf{1 . 3 8 8}$ & $\mathbf{0 . 1 6 7}$ & \\
\hline FCF & + & $\mathbf{0 . 0 0 7}$ & $\mathbf{0 . 3 7 7}$ & $\mathbf{0 . 7 0 7}$ & $\mathbf{4 . 5 9 8}$ \\
\hline GWOPR & - & $\mathbf{0 . 0 3 0} *$ & $\mathbf{2 . 8 6 2}$ & $\mathbf{0 . 0 0 5}$ & $\mathbf{1 . 2 8 9}$ \\
\hline FCF*GWOPR & - & $\mathbf{0 . 0 1 4}$ & $\mathbf{0 . 6 8 7}$ & $\mathbf{0 . 4 9 3}$ & $\mathbf{4 . 6 5 2}$ \\
\hline FROE & + & $\mathbf{0 . 0 0 1}$ & $\mathbf{0 . 0 8 6}$ & $\mathbf{0 . 9 3 2}$ & $\mathbf{1 . 0 9 7}$ \\
\hline FSIZE & + & $\mathbf{- 0 . 0 0 3}$ & $\mathbf{- 0 . 8 9 0}$ & $\mathbf{0 . 3 7 5}$ & $\mathbf{1 . 4 5 5}$ \\
\hline FLEVG & - & $\mathbf{- 0 . 0 4 4 ^ { * }}$ & $\mathbf{- 2 . 1 0 7}$ & $\mathbf{0 . 0 3 7}$ & $\mathbf{1 . 5 3 3}$ \\
\hline Adjusted R Sq. value & & $\mathbf{0 . 0 8 8}$ & & \\
\hline F & & $\mathbf{3 . 1 2 8} *$ & & \\
\hline P. value & & $\mathbf{0 . 0 0 7}$ & & & \\
\hline Durbin-Watson & & $\mathbf{1 . 9 8 8}$ \\
\hline $\begin{array}{l}\text { Kolmogorov- } \\
\text { Smirnov Z Sig. }\end{array}$ & & $\mathbf{0 . 1 3 6}$ &
\end{tabular}

Notes: $(* *)$ and $(*)$ denote the significance of the parameter estimated at the 0.01, 0.05 levels, respectively

Table (4) reports the regression results where dividend policy is represented by dividend payouts (DIVIDPAYOUT) as well the potential interactive effect of firm's growth opportunities on the relationship between free cash flow with dividend payouts. The model is significant $(\mathrm{F}=2.748$, P-Value $<0.05)$. The combination of the independent variables explains $7.40 \%$ of the variations in dividend payouts. The coefficient estimate of free cash flow (FCF) is $(0.212)$ with t-statistics (0.543), indicating an insignificant relationship with dividend payouts. This result is inconsistent with what was hypothesized.

The coefficient of growth opportunity (GWOPR) is positive and statistically significant with dividend payouts. This finding is inconsistent with what was hypothesized. The coefficient of the interaction of free cash flow $*$ growth opportunities (FCF*GWOPR) is positive but statistically insignificant with dividend payouts. This result suggests that growth opportunities do not play a moderating role in the hypothesized relationship of free cash flow and dividend payouts. This finding is inconsistent with prior research and what it was hypothesized in $\mathrm{H} 2$, which posited that high-growth firms are more likely to distribute lower dividends than low-growth firms in order to benefit from the available investment 
opportunities. However, this result is in line with the findings of Kargar and Ahmadi (2013) that reported a positive but insignificant association between free cash flow and dividend payouts in either high or low-growth firms.

Concerning the other control variables, the coefficient estimate for firm profitability (FROE) is (0.026), whereas for firm size (FSIZE) is (-0.085), indicating no significant relation with dividend payouts, except for financial leverage (FLEVG); financial leverage has coefficient estimate of (-0.999) with dividend payouts, reflecting a statistically significant negative relationship with dividend payouts. This finding is consistent with the findings of Roseff (1982), Nurul and Iqbal (2015) and Tijjani and Sani (2016) that reported a negative causal relation between debt levels and dividend payments.

Table (4)

Dividend Policy represented by Dividend Payout (DIVIDPAYOUT)

\begin{tabular}{|l|c|c|c|c|c|}
\hline & $\begin{array}{c}\text { Predicted } \\
\text { Sign }\end{array}$ & Coefficient & $\begin{array}{c}\text { t. } \\
\text { statistics }\end{array}$ & Sig. & VIF \\
\hline Intercept & & $\mathbf{2 . 4 9 6}$ & $\mathbf{1 . 4 3 3}$ & $\mathbf{0 . 1 5 4}$ & \\
\hline FCF & + & $\mathbf{0 . 2 1 2}$ & $\mathbf{0 . 5 4 3}$ & $\mathbf{0 . 5 8 8}$ & $\mathbf{4 . 6 0 5}$ \\
\hline GWOPR & - & $\mathbf{0 . 5 4 7} *$ & $\mathbf{2 . 3 5 7}$ & $\mathbf{0 . 0 2 0}$ & $\mathbf{1 . 3 3 8}$ \\
\hline FCF*GWOPR & - & $\mathbf{0 . 2 1 6}$ & $\mathbf{0 . 4 8 8}$ & $\mathbf{0 . 6 2 7}$ & $\mathbf{4 . 6 8 5}$ \\
\hline FROE & + & $\mathbf{0 . 0 2 6}$ & $\mathbf{0 . 1 2 3}$ & $\mathbf{0 . 9 0 2}$ & $\mathbf{1 . 0 9 8}$ \\
\hline FSIZE & + & $\mathbf{- 0 . 0 8 5}$ & $\mathbf{- 1 . 0 4 4}$ & $\mathbf{0 . 2 9 8}$ & $\mathbf{1 . 5 2 4}$ \\
\hline FLEVG & - & $\mathbf{- 0 . 9 9 9 *}$ & $\mathbf{- 2 . 1 2 3}$ & $\mathbf{0 . 0 3 6}$ & $\mathbf{1 . 6 1 9}$ \\
\hline Adjusted R Sq. value & & $\mathbf{0 . 0 7 4}$ & & \\
\hline F & & $\mathbf{2 . 7 4 8}$ & & \\
\hline P. value & & $\mathbf{0 . 0 1 5}$ & \\
\hline Durbin-Watson & & $\mathbf{2 . 0 6 9}$ \\
\hline $\begin{array}{l}\text { Kolmogorov- } \\
\text { Smirnov Z Sig. }\end{array}$ & & $\mathbf{0 . 5 5 5}$ & \\
\hline
\end{tabular}

Notes: (**) and $(*)$ denote the significance of the parameter estimated at the 0.01, 0.05 levels, respectively

The overall results supported insignificant associations between free cash flow with dividend size and dividend payouts. These results are consistent with the findings of Giriati (2015) and Wijaya and Felix (2017) who found an insignificant association between free cash flow and dividend payments. Also, in the presence of growth opportunities, the relationship between free cash flow and dividend size does not affected, suggesting that growth opportunities do not play a moderating role, same conclusion for dividend payouts. Two possible explanations for the 
preceding results; the first is related to the recent update on Egyptian income tax law with respect to capital gains and dividends distribution in July 2014. According to this new update ${ }^{(5)}$, cash dividends distributed to natural persons resident in Egypt are applied to taxes whether these cash dividends are realized in Egyptian stock exchange (received from listed Egyptian companies) or abroad (received from companies listed in foreign stock exchanges).

The new update had too many negative consequences on the Egyptian Stock Exchange. Egyptian stock exchange had witnessed a significant decline in cash dividends distribution rate by more than $38 \%$ from 9.7 billion EGP to 5.9 billion EGP, while the number of companies that announced cash dividends had declined from 75 companies to 56 companies from July 2014 up to April 2015, compared with the same period of the previous year (CNBC Arabia, 2015). Moreover, companies preferred to distribute stock dividends as an alternative to cash dividends, as stock dividends are not subject to taxes. Under a great pressure from investors in the Egyptian stock exchange, the preceding update in income tax law had been suspended (but not had been canceled) by the Egyptian government for two years from 2015 until 2017 (Reuters, 2017).

Although the Egyptian government had approved to freeze the preceding update in income tax law; this may suggest the possibility of relying on other control mechanisms (i. e. leverage), beside dividends payouts, in order to control the potential overinvestment and other potential misuses of firms' excess resources by opportunistic managers for their own private benefits. Debts could restrict firm's available resources from being inefficiently used by opportunistic managers through giving it directly to debt holders in the form of principal and interest payments. The preceding explanation is also supported by Jensen (1986) hypothesis of free cash flow, which represents the second possible explanation for interpreting the results. Jensen (1986) stated the possibility to spend excess cash flow that was internally generated for the private benefits and short-term interests of opportunistic managers rather than spending on maximizing shareholders value. Jensen (1986) proposed debts in addition to dividend payments as two possible mechanisms to reduce the agency costs of the free cash flow. Jensen (1986) argued that, by issuing

5 - It is important to mention that the recent update on Egyptian income tax law with respect to capital gains and dividends distribution occurred during the same years of the study period. 
debts, managers are obligated to pay out the future cash flow in such a way that cannot be accomplished by promises to increase future dividends payments. Such weak promises can be cut in the future for any reason.

Roseff (1982) also the view that dividend payments are quasi-fixed charges that are considered substitutes for other fixed charges (i. e. interest payments). Consistent with this view, the findings of Hashemi and Zadeh (2012) and Hejazi and Moshtaghin (2014) who supported the argument that leverage and dividends are substitutes to control free cash flow problem. Wu (2004) examined the relationship between free cash flow and leverage and found significant positive relationship between leverage and free cash flow; however, this relationship is greater for lowgrowth firms than for high-growth firms using a sample of Japanese listed firms during 1992 to 2000. Kargar and Ahmadi (2013) examined also the impact of free cash flow on leverage and found a positive significant association between leverage and free cash flow for low-growth firms whereas a positive but insignificant association for high-growth firms.

Based on the preceding discussion, the regression analyses will be expanded in order to empirically explore the potential association between free cash flow and financial leverage as well the potential interactive effect of firm's growth opportunities on the relationship between free cash flow and financial leverage. Consistent with prior literature, a positive association is expected between the level of free cash flow and financial leverage and this relationship is positive and stronger for low-growth firms than high-growth firms:

Hypothesis III: the relation between the level of free cash flow and financial leverage is positive and stronger for firms with low growth opportunities than high growth opportunities.

The following model is constructed to provide empirical testing to the preceding hypothesis:

$$
\begin{aligned}
& F L E V G_{i t}=\beta_{0}+\beta_{1}(F C F)_{i t}+\beta_{2}(G W O P R)_{i t}+\beta_{3}(F C F)_{i t} *(G W O P R)_{i t}+\beta_{4} \\
& (F P R O F)_{i t}+\beta_{5}(F S I Z E)_{i t}+\varepsilon_{i t}
\end{aligned}
$$


Where,

Financial leverage (FLEVG) is measured by Debt /Asset ratio, free cash flow (FCF) is measured by subtracting capital expenditures from company's operating cash flow divided by book value of assets. Growth opportunities (GWOPR) is a moderator variable and Market-to-book ratio of equity is used to measure firm's growth opportunities. Profitability (FROE) is measured by return on equity ratio. Firm size (FSIZE) is measured by the natural log of total assets.

Table (5) presents the regression results examining the potential effect of free cash flow on financial leverage and the interactive effects of firm's growth opportunities on the relationship between free cash flow and financial leverage. The model is highly significant $(\mathrm{F}=13.347$, P-Value $<0.00)$, implying that the regression model has a good explanatory power of financial leverage. The combination of the independent variables explains $31.7 \%$ of the variations in financial leverage. The coefficient estimate for free cash flow (FCF) is $(0.168)$ with t-statistics of (2.217). Free Cash flow (FCF) has a positive significant relation with financial leverage (FLEVG). This finding is consistent with what was expected that higher levels of free cash flow are associated with higher financial leverage, since debt is viewed as a possible control mechanism to mitigate potential misuse of excess resources by opportunistic managers for their own private benefits. This result is also consistent with the findings of Wu (2004) and Kargar and Ahmadi (2013) that reported a positive association between free cash flow and financial leverage. The coefficient of growth opportunity (GWOPR) is positive and statistically significant with financial leverage. This finding is inconsistent with Gul (1998) that reported a negative association between levels of debt financing and growth opportunities.

Jensen (1986) argued that the control function of leverage is more important in firms that generate higher level of cash flow but have lower growth opportunities; in low-growth firms, the probability to waste the excess free cash flow in uneconomic projects is higher. Consistent with the argument of Jensen (1986), the coefficient of the interaction of free cash flow * growth opportunities $(\mathrm{FCF} * \mathrm{GWOPR})$ is negative and statistically significant at 0.05 with financial leverage. This result suggested that growth opportunities play a moderating role in the hypothesized relationship of free cash flow and financial leverage. Turning to 
the other explanatory variables, the coefficient estimates for firm profitability (FROE) is (0.049), whereas for firm size (FSIZE) is (0.080), indicating positive associations with debt financing.

Table (5)

Additional Regression Results

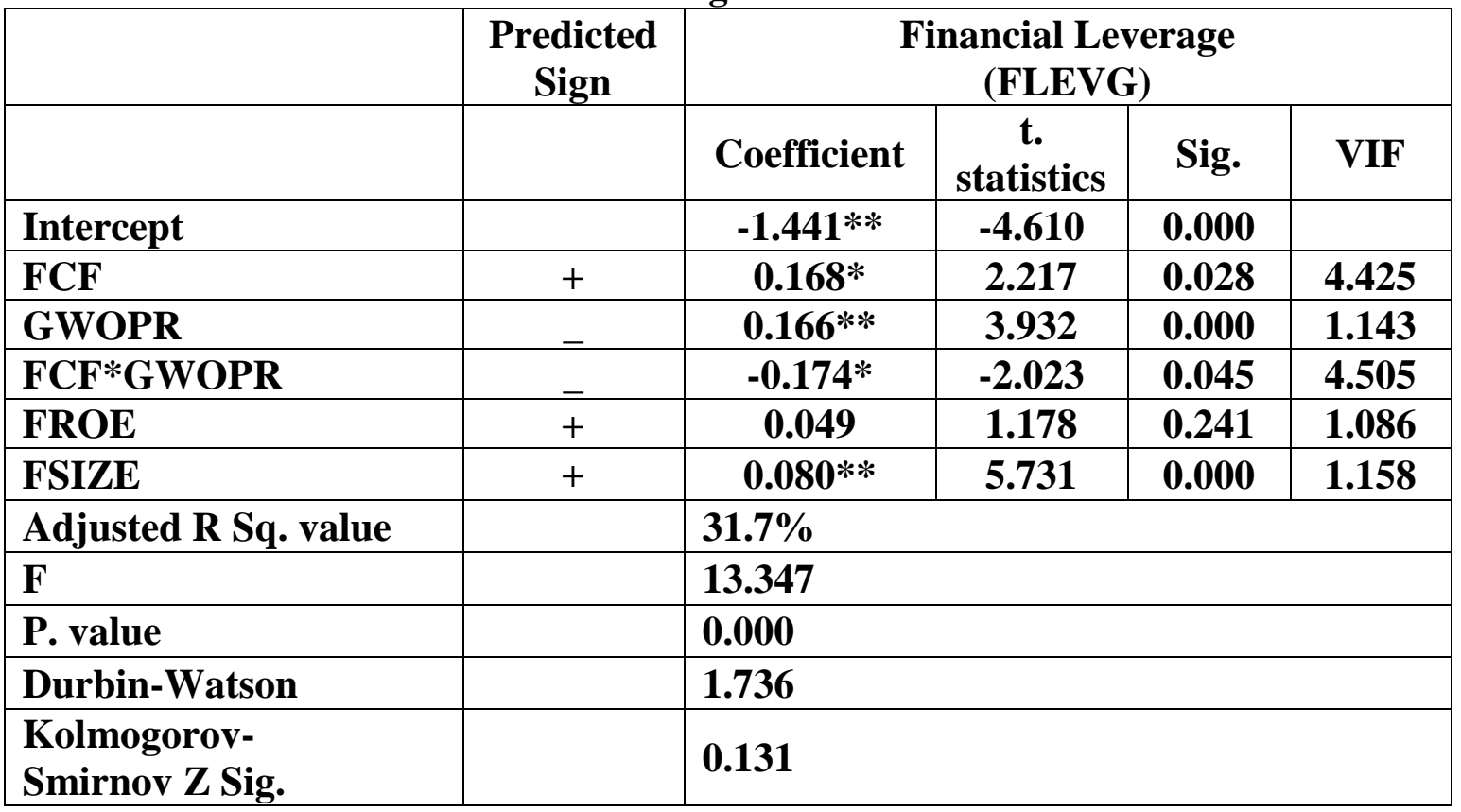

Notes: $(* *)$ and $(*)$ denote the significance of the parameter estimated at the 0.01, 0.05 levels, respectively

The overall result supports a significant positive association between free cash flow and financial leverage. This finding supports the notion that the debts can be used as alternative control mechanism for reducing of agency costs of the free cash flow by reducing the excess free cash flow that is under discretionary control of the manager. This conclusion is consistent with the findings of Kargar and Ahmadi (2013), Hejazi and Moshtaghin (2014) Nurul and Iqbal (2015). This result is consistent the view of Roseff (1982) and Jensen (1986) hypothesis of free cash flow; leverage is another mechanism for reducing of the agency cost of the free cash flow.

\section{CONCLUSION}

Dividend policy should be a response to two factors; firm's available resources (i.e. free cash flow) and the available growth opportunities that will maximize shareholders value (Cheng et al., 2014; Wijaya and Felix, 2017). When 
the retained resources are more than what is required to finance worthwhile investment opportunities - the case where the company pays out low or no dividends - the retained cash may be misused by opportunistic management for their own private benefits or in inappropriate projects (Stouraitis and Wu, 2004; Khan et al. 2012).

The present study examined the potential impact of free cash flow on dividend policy (presented by dividend size and dividend payouts) as well the potential interactive effects of firm's growth opportunities on the relationship between free cash flow with dividend size and dividend yield. The empirical results showed positive but insignificant association between free cash flow and dividend size. The study also found that, in the presence of growth opportunities, the relationship between free cash flow and dividend size was not affected which means that growth opportunities did not moderate the hypothesized relationships. Same conclusion is reported for dividend payouts.

The preceding results suggested that the Egyptian listed companies, regardless of the availability of growth opportunities, do not extensively rely on dividends as a controlling mechanism to reduce agency costs of free cash flow. Two possible explanations behind these insignificant relationships; first, a recent update on Egyptian income tax law with respect to capital gains and cash dividends distribution, which imposes taxes on cash dividends distributions to natural persons resident in Egypt whether cash dividends are realized in Egypt or abroad. This new update had too many negative consequences on the Egyptian Stock Exchange that forced the Egyptian government to freeze it under great scrutiny pressure from investors in Egyptian stock exchange for two years.

The update had been suspended; however, this may point to the possibility of relying on another control mechanism (i.e. leverage) to mitigate the potential overinvestment and other potential misuses of resources by opportunistic managers. Leverage could restrict the available resources from being inefficiently used by opportunistic managers by paying it to debt holders in the form of principal and interest payments. The preceding explanation is supported by Jensen (1986) hypothesis of free cash flow, which states the possibility to use the excess cash flow on private benefits and short-term interests of managers rather than in worthwhile investments that will maximize shareholders value. Jensen (1986) proposed debts as a substitute for dividend policy to reduce the agency costs of the free cash flow. He argued that issuing debts can obligate managers to pay out the future cash flow 
in such a way that could not be accomplished with simple increases in dividends payments. This view is supported also by Roseff (1982) who argued that dividend payments are considered quasi-fixed charges which are substitutes for other fixed charges (i. e. interest payments).

Based on the preceding possible explanations, the present study expanded the regression analyses to examine the potential impact of free cash flow on financial leverage as well the potential interactive effect of firm's growth opportunities on the relationship between free cash flow and financial leverage. The empirical results reported positive and significant association between the level of free cash flow and financial leverage. This result supported the notion that financial leverage is used as another control mechanism to reduce the agency costs of free cash flow. This conclusion is consistent with the research findings of Kargar and Ahmadi (2013) Hejazi and Moshtaghin (2014) Nurul and Iqbal (2015). The study also found that growth opportunities play a moderating role in the hypothesized relationship of free cash flow and financial leverage.

The overall results revealed that firm leverage can be used in mitigating agency cost of free cash flow by decreasing free cash flow that is under discretionary control of managers because of the contractual obligation associated with high level of financial leverage to pay periodic interest on debt and repay the borrowed capital at maturity. This result is consistent with Jensen (1986) hypothesis of free cash flow. In Egyptian firms, leverage is a more effective way to mitigate the agency cost of free cash flow than dividend policy. High leverage increases creditors' concerns about the interest and principal payments so it adds more incentives for monitoring the manager's action.

\section{REFERENCES}

Abdelsalam, O., El-Masry, A., \& Elsegini, S. (2008). Board composition, ownership structure and dividend policies in an emerging market: Further evidence from CASE 50. Managerial Finance, 34(12), 953-964.

Bhabra, G., \& Luu, K. H. (2015). Growth, governance and corporate payout policy. Accounting \& Finance, 55(3), 659-681.

CNBC Arabia. (2015, April 16). The Egyptian income tax law on capital gains reflected negatively on cash dividends in the Egyptian stock exchange. Retrieved from https://www.cnbcarabia.com/news/view/9223/program/43. 
Cheng, Z., Cullinan, C. P., \& Zhang, J. (2014). Free cash flow, growth opportunities, and dividends: Does Cross-Listing of shares matter?. Journal of Applied Business Research, 30(2), 587-598.

Ghalandari, K. (2013). The moderating effects of growth opportunities on the relationship between capital structure and dividend policy and ownership structure with firm value in Iran: Case Study of Tehran Securities Exchange. Research Journal of Applied Sciences, Engineering and Technology, 5(4), 1424-1431.

Giriati, P. (2015). Free cash flow, dividend policy, investment opportunity set, opportunistic behavior and firm's value: A study about agency theory. Social and Behavioral Sciences, 219 (2016), 248 - 254.

Gul, F. A. (1999). Growth opportunities, capital structure and dividend policies in Japan. Journal of Corporate Finance, 5(2), 141-168.

Hashemi, S. A., \& Zadeh, Z. K. (2012). The impact of financial leverage, operating cash flow and size of company on the dividend policy (case study of Iran). Interdisciplinary Journal of Contemporary Research in Business, 3(10), 264-270.

Hejazi, R., \& moshtaghin Fatemeh, S. (2014). Impact of agency costs of free cash flow on dividend policy, and leverage of firms in Iran. Journal of Novel Applied Sciences, 3(1), 14-21.

Jensen, M. C. (1986). Agency costs of free cash flow, corporate finance, and takeovers. The American Economic Review, 76(2), 323-329.

Kangarlouei, S. J., Ramizipour, B., \& Motavassel, M. (2014). Investigation of the Impact of free cash flows on financial flexibility and dividend policy in firms listed in Tehran Stock Exchange. International Journal of Banking, Risk and Insurance, 2(2), 1 .

Kargar, E. F., \& Ahmadi, G. R. (2013). The relationship between free cash flows and agency costs levels: evidence from Tehran Stock Exchange. Research Journal of Finance and Accounting, 4(14), 51-65.

Khan, A., Kaleem, A., \& Nazir, M. S. (2012). Impact of financial leverage on agency cost of free cash flow: Evidence from the manufacturing sector of Pakistan. Journal of Basic and Applied Scientific Research, 2(7), 6694-6700.

Mirza, H., \& Afza, T. (2014). Impact of corporate cash flow on dividend payouts: Evidence from South Asia. Middle-East Journal of Scientific Research, 19 (4), 472478. 
Nurul, F., \& Iqbal, M. (2015). The effect of free cash flow, dividend policy and growth opportunity to debt policy in manufacturing company listed on BEI. International Journal of Environmental Research, 12(5), 1647-1669.

Parsian, H., \& Shams Koloukhi, A. (2013). A study on the effect of free cash flow and profitability current ratio on dividend payout ratio: Evidence from Tehran Stock Exchange. Management Science Letters- Growing Science, 4(1), 63-70.

Reuters. (2017, March 21). Egypt extends capital gains tax freeze, approves stamp duty on stocks. Retrieved from https://www.reuters.com/article/egypt-economytax/update-1-egypt-extends-capital-gains-tax-freeze-approves-stamp-duty-onstocks-idUSL5N1GY6G0.

Rozeff, M. S. (1982). Growth, beta and agency costs as determinants of dividend payout ratios. Journal of financial Research, 5(3), 249-259.

Stouraitis, A., \& Wu, L. (2004). The impact of ownership structure on the dividend policy of Japanese firms with free cash flow problem. In AFFI December Meeting, $23 r d$.

Sualehkhattak, M., \& Hussain, M. (2017). Do growth opportunities influence the relationship of capital structure, dividend policy and ownership structure with firm value: Empirical evidence of KSE?. Journal of Accounting \& Marketing, 6(1), 1-11.

Subramaniam, R. K., Shaiban, M., \& Suppiah, S. D. K. (2014). Growth opportunities and dividend policy: Some evidence on the role of ethnicity in an emerging economy. Corporate Ownership \& Control, 12(1), 126-139.

Subramaniam, R., Devi, S. S., \& Marimuthu, M. (2011). Investment opportunity set and dividend policy in Malaysia. African Journal of Business Management, 5(24), 10128.

Tijjani, B., \& Sani, A. U. A. (2016). An empirical analysis of free cash flow and dividend policy in the Nigerian oil and gas sector. Research Journal of Finance and Accounting, 7(12), 153-160.

Ullah, H., Fida, A., \& Khan, S. (2012). The impact of ownership structure on dividend policy evidence from emerging markets KSE-100 Index Pakistan. International Journal of Business and Social Science, 3(9). 298-307.

Wijaya, N., \& Felix, A. (2017). Factors affecting dividend policy on non-financial companies in Indonesia. Accounting and Finance Review, 2(3), 18 - 25.

Wu, L. (2004). The impact of ownership structure on debt financing of Japanese firms with the agency cost of free cash flow. Department of Economics and Finance. City University of Hong Kong. 